\title{
The influence of financial critical success factors on project success: Evidence from several electric power projects in Iraq
}

\author{
Aymen Raheem Abdulaali ${ }^{1}$, Alhamzah Alnoor ${ }^{2}$, Dr. Hadi Al-Abrrow ${ }^{3}$, Hasan Oudah \\ Abdullah $^{4}$, Sammar Abbas ${ }^{5}$ \\ \{aymen.abdulali@stu.edu.iq ${ }^{1}$, alhamzah.malik@stu.edu.iq ${ }^{2}$, hauni_2000@yahoo.com ${ }^{3}$, \\ hasan_oudah@yahoo.com ${ }^{4}$, sabbas@kust.edu.pk ${ }^{5}$ \} \\ Southern Technical University, Management Technical College-Iraq ${ }^{1}$ \\ Southern Technical University, Management Technical College-Iraq, School of Management, University \\ Sains Malaysia, 11800 Pulau Pinang, Malaysia ${ }^{2}$ \\ Department of Business Administration, College of Administration and Economics, University of \\ Basrah, Iraq ${ }^{3}$ \\ Department of Business Administration, Basrah University College for Science and Technology, $\operatorname{Iraq}^{4}$ \\ Institute of Business Studies, Kohat University of Science and Technology, Pakistan ${ }^{5}$
}

\begin{abstract}
This research seeks to provide a practical and theoretical framework on "The Impact of Critical Success Factors on the Project's Success." The questionnaire and the personal interview were used as a data collection method for the study, and the sample size was 15 employees. Several statistical methods were used to test the study hypotheses. The results showed a positive effect of the critical success factors on the success of the project and their clarification of the existence of a positive correlation between the essential elements of success in the success of the project. The novelty of the context under the given circumstances of Covid-19 adds to the originality of this study. Several previous studies have also emphasized the need for this type of study in other contexts. The findings can call managers' attention to a critical issue of project success in electric power projects.
\end{abstract}

Keywords: critical success, project success, electric power projects

\section{Introduction}

The variables that appeared in the work environment and their impact put pressure on organizations to perform efficiently and effectively to compete in the market, the most important of which is globalization (Alias et al., 2014). The restrictions were abolished, and this made organizations face severe and continuous changes in the work environment. Marketing gaps became under attack, so the various departments resorted to formulating cautious strategies and implementing them accurately. Any mistake can cause a severe crisis and a threat of failure (Westerveld, 2003). These errors may be caused by a group of factors characterized by being the most critical to getting rid of loss called the essential factors of success, which are the entrance that was established and popularized over the past thirty years and since then it has been the focus of the attention of writers and researchers to this day because it can be considered as a warning sign and alert about the dangers facing the organization (Thi \& Swierczek, 2010). Accordingly, and based on the importance of the topics of the study, and in continuity with 
previous research efforts in increasing intellectual enrichment in these topics, this study came to focus on the following question: "To what extent do critical success factors contribute to the success of project management?".

The previous regime - due to the lack of serious interest in construction and services, and spending most of the country's resources in wars and problems that the previous administrations created or were involved in, and the result was that the cities of Iraq became like cities, devoid of the manifestations of reconstruction and lacking the simplest services, and they are to the villages closer than to the cities - despite the presence of disparity in that, between a town and another for incorrect considerations - and after the fall of the regime, people rejoiced in the new situation, perhaps changing something from this bad reality, but with all the regret, things did not go as they should be for many reasons, most of which are unconvincing, despite the magnitude of the defect left by the former regime that exists in construction and services in the governorates and the need for huge and exceptional funds and efforts to address this imbalance, and the impossibility of implementing this in a short time, but the process of reconstruction and implementation of government projects is going in many cases. We have wrong aspects of it, which made us call it the title of the problem (Al-Abrrow et al., 2019). The problem of construction and implementation of government projects is not a single problem. Still, it addresses a group of issues that led to the emergence of reconstruction and services in the current bad manner. Through field visits to electric power projects and reviewing the completion rates of projects implemented by private companies, it was found that many problems led to the resulting delay of a large part of these projects (Alnoor, 2020).

\section{Literature Review}

\subsection{Critical success factors}

Critical Success Factors The approach that was established and popularized among people over the past thirty years by several researchers and writers, where consultants and various departments have increasingly used this approach as a means of support for strategic planning, which led to an increasing and great interest in it from analysts and researchers (Ahmadabadi \& Heravi, 2019). In 1961, Ronald Daniel launched the term success factors and used this term to define the information needed in the performance of administrative duties. It also suggested that information systems in the organization should focus on the success factors in most industries from three to six factors (Müller \& Jugdev, 2012). Munro \& whether defined it as the success or failure of the organization's effort to form the strategic plan and identify the main problems that arise from the strategic implementation process (Zwikael \& Globerson, 2006). While a potential or actual crisis, decision, or plan that, if left unresolved, affects the application of the driving force of the organization or any of the essential elements of the strategy such as competitive advantage, key capabilities, the desire to enter new systems, or expectations of return and growth. It may have a big role in the organization's failure (Gemuenden \& Lechler, 1997). The critical success factors are those components required to create an environment for the success and excellence of projects. The project's success is usually recognized through the recognition of customer satisfaction, which has become increasingly important due to the competitive nature of the market and the uncertainty of the environment (Ika et al., 2012).

Through the previous presentation of the concept of critical success factors (CSFs) and their nature, we noted the role and importance of these factors in organizations in general and the 
project's success. Therefore, this topic has received the attention of academic and professional organizations on the one hand, and writers and researchers, on the other hand, to reach the full benefit of the application - this method by identifying the various aspects related to it. Through the desk tracking of these efforts, the researcher got a set of reasons behind the importance of critical success factors (CSFs) for organizations. These reasons are:

1. Critical Success Factors (CSFs) are closely related to the organization's long-term goals. If these factors are effectively identified, the organization will be in a better position to achieve these goals (Belout \& Gauvreau, 2004).

2. The success of applying critical success factors in different organizations and fields such as health care, academic institutions, industrial organizations, social institutions, and others (Pinto \& Slevin, 1989) and their importance to individuals within those organizations and at various administrative levels.

3. Critical Success Factors (CSFS) focus on determining the information of strategic planning and management control required from senior management and then linking this method to determining the strategic direction of organizations (Ika et al., 2012).

4. These factors constitute the vital elements of organizations, meaning that the failure of these factors will lead to the loss of those organizations. Accordingly, they are - that is, the factors critical failure factors for organizations (Andersen et al., 2006).

Most researchers also agree on the importance of the critical elements of success and the need to define them as a prerequisite for competitive success and as a top priority in the analytical aspect because the organization needs to know which resources have a higher competitive value and what are the elements of sustainable competitive success to be able to direct its strategy in the right direction and devote its energy to excellence in one or More than these factors as an opportunity to obtain a sustainable competitive advantage (Fan, 2010). Therefore, successful organizations must face the fact that everything is changing, and that yesterday's world is gone, and organizations must adopt the method of a rapid transition in the stage. Thus, the critical elements of success are one of the most important tools for identifying information needs, which is the first crucial step in the development, design, or process of choosing a system (Rosacker \& Olson, 2008).

\subsection{Project success}

Success is shrouded in ambiguity, as it is an extended term with multiple directions and implications. The confusion in the views around it confirms this ambiguity because "success is unknown by its nature." Nevertheless, it has become clear that success is an important and complex expression to explore (Mavi \& Standing, 2018). Most of this difference lies in two important things: the factors that cause success in organizations and the measures used to measure success in them, as effectiveness and efficiency are criteria for measuring the organization's success through its quest to continue its activities achieve its goals. And organizational success is a composite measure that combines them, and therefore, it is more comprehensive than either of them (Bradley, 2008).

All organizations of all kinds, objectives, and activities need to use criteria to judge the organization's success. However, that only one criterion can be determined to judge the success of the organization. It is no longer acceptable to believe that there is one global standard to evaluate the success of organizations. It is difficult to find an organization that is successful in 
all aspects or a failure in everything. The criteria of efficiency and effectiveness can be used to judge the organization's success (Tsiga et al., 2017). Efficiency and effectiveness are two sides of the same coin: the successful or effective organization. The source of this relationship is their direct relationship to achieve goals and maintain the organization's survival, growth, and development. And suppose effectiveness is the basis of the success of the organization. In that case, efficiency is a condition for its survival, after it has achieved success because the first is the essence of the organization. A guide for its managers in the performance of organizational activities, then increase returns and effective investment of capital, in a way that is reflected on the welfare of society and its members, because this is linked to the provision of goods and services with high quality, providing job opportunities for individuals, giving a clear view of the health of the organization's work (Banihashemi et al., 2017). The concept of efficiency is inherent in the idea of effectiveness, but it cannot be mutual. The organization may be effective but not efficient. It achieves its goals but with a loss, and the organization's inefficiency negatively affects its effectiveness. The higher the costs of achieving a particular purpose, the lower the chances of the organization's ability to survive and succeed (Haq et al., 2019). Efficiency can be used as a long-term measure, while efficiency can be considered as a shortterm measure. Effectiveness is the basis of success; Efficiency is the minimum condition for survival after success (Vrchota et al., 2021).

For an organization to be successful, it must be run as an open system. The organization must find and obtain the necessary resources, interpret, and act on environmental threats and opportunities, distribute products and services, and control and coordinate internal activities in the face of external changes and uncertainty. Organizations can increase their success by providing appropriate methods and tools to enhance success (Osei-Kyei \& Chan, 2017). Furthermore, successful organizations must balance their needs, aspirations, and constraints against the greater interests of the communities in which they operate. At the same time, internal resources determine organizational success. These resources can be either tangible or intangible assets or capabilities, such as accumulated knowledge and skills. Intangible resources are more important than substantial resources for the effectiveness and success of organizations (Belout \& Gauvreau, 2004).

Determining the main features of project success is one of the important topics for project owners and contractors to achieve effective success in project implementation. However, studies indicate that there is a difference between various researchers to choose the basic features to determine the success of the project, not that there is almost agreement between researchers in identifying three basic factors that represent the essential dimensions for the success of the project (Zwikael \& Globerson, 2006; Al-Abrrow et al., 2019).

\section{Scheduling}

All projects are restricted to a specific period for project completion. Completing the project on time is a major challenge for project management and a major criterion for project success by the owner, contractor, and consultant.

\section{Cost}

Financial resources are a key factor in the continuity of project implementation, as the owner (the project owner) is considered the lower the project's costs, the higher its profits. Hence, many owners evaluate and choose offers based on the price offered by the contractor. 


\section{Quality}

Quality is the approved standards for accepting the final product or project, implementation stages, and compliance with the required specifications. Based on the previous discussion, it can be assumed $\mathrm{H} 1$ to $\mathrm{H} 21$ : There is an influence relationship between the dimensions of the independent variable critical success factors and the dimensions of the dependent variable project success. Fig 1. shows the proposed study model based on what was mentioned in the previous sections.

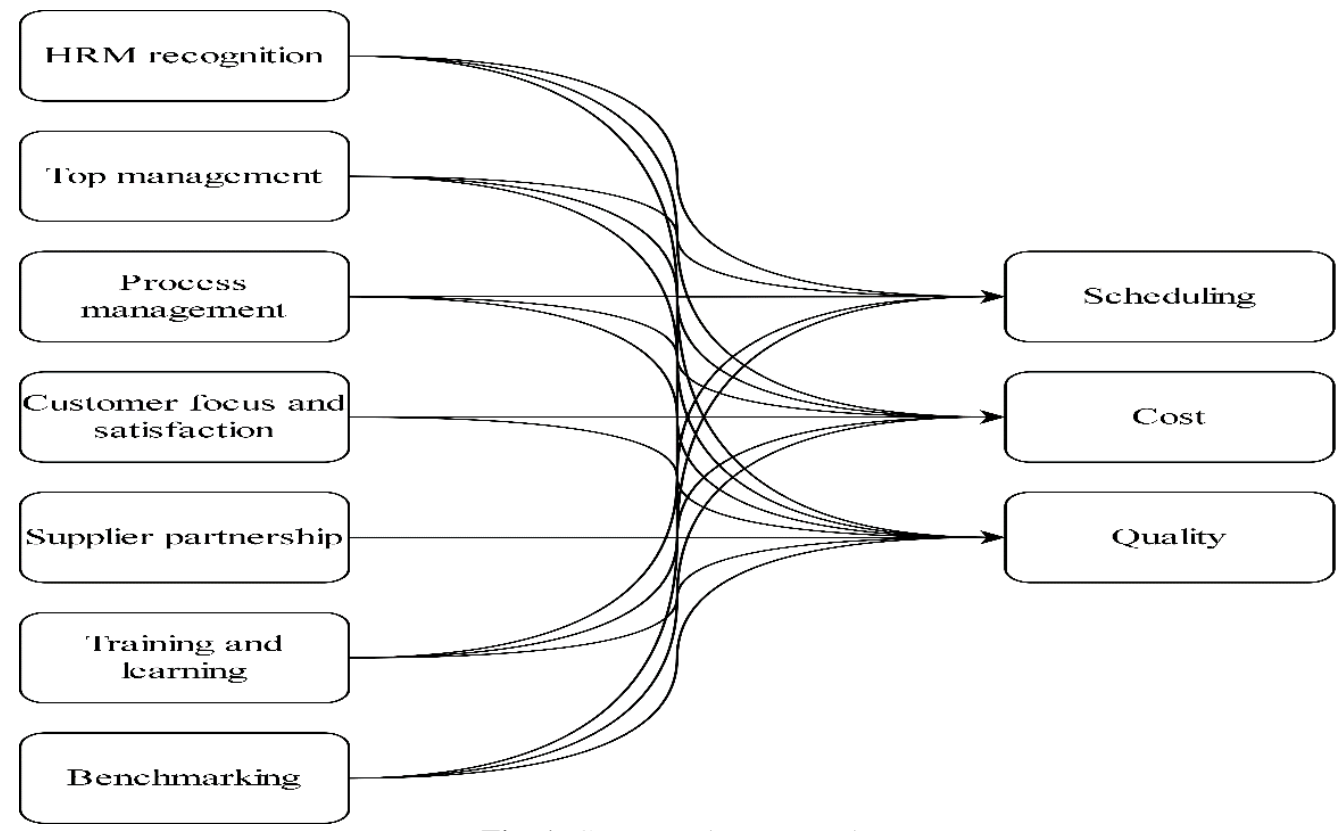

Fig. 1. Conceptual Framework.

\section{Methodology}

In this study, the opinions of several individuals working in several electric power projects were surveyed, and the study sample was represented by 233 individuals who were chosen randomly, based on Roscoe (1975), who believes that the sample size between (30-500) is suitable for various studies. Of the 233 questionnaires that were sent online with the help of human resource managers in the projects, 221 questionnaires were obtained. Furthermore, the response rate for this study was $94 \%$. The questionnaire was translated and distributed for understanding by the respondents (the intended sample of the research). The questionnaire was relied upon because the researchers had accurate knowledge of what was required and how to measure the variables to be studied. And the (Likert) quintuple scale was relied on, which is graded according to the following answers (not completely agree "1", disagree "2", agree to some extent " 3 ", agree " 4 ", completely agree "5") 
The issue of bias is just normal in human resources research, particularly concerning questionnaires geared toward self-reports. As an answer to the problem, some preventive measures were implemented, such as guaranteeing the confidentiality of information for respondents, inversion of scale items (back translation) was formulated, and separate sources of data on the independent and dependent variables were used, 360-degree employee evaluation surveys were constructed to deal with bias (Podsakoff, MacKenzie, Lee, \& Podsakoff, 2003). The 28 items were adopted according to the Hietschold et al. (2014) scale, which was used to measure sustainable performance. In addition, the project success was estimated based on (AlAbrrow et al., 2019). Therefore, this study has been used nine times for project success. The final sample consisted of 74 administrators and 147engineers, representing $44 \%$ of males and $54 \%$ of females. Those with a diploma represented the majority at a rate of $65 \%$, while the percentage of those who obtained a bachelor's degree was $15 \%$ of the sample, masters, and doctorates were $20 \%$. The age group between $35-45$ was the largest percentage, $67 \%$.

\section{Results}

This study relied on several standards used previously in the management literature, characterized by stability and high credibility. Therefore, loading factor, Cronbach's alpha (CA), average variance extracted (AVE), composite reliability (CR) was adopted for the convergent validity test. The AVE value must be greater than 0.5 , while consistency reliability $(\mathrm{CR})$ must be greater than 0.7 . In addition, the loading factor should be more than 0.7 (Hair et al., 2019). Table 1 shows that all criteria were met, indicating the model's reliability, as the AVE was greater than 0.5 and the $\mathrm{CR}$ was greater than 0.7 , while the loading factors were greater than 0.7 .

Table 1. assessment of the measurement model.

\begin{tabular}{|c|c|c|c|c|}
\hline Construct & Items & Loadings & $\mathbf{C R}$ & AVE \\
\hline \multirow{4}{*}{ HRM recognition } & Q1 & 0.832 & 0.836 & 0.625 \\
\hline & Q2 & 0.835 & & \\
\hline & Q3 & 0.896 & & \\
\hline & Q4 & 0.864 & & \\
\hline \multirow{4}{*}{ Top management } & Q5 & 0.838 & 0.885 & 0.735 \\
\hline & Q6 & 0.880 & & \\
\hline & Q7 & 0.833 & & \\
\hline & Q8 & 0.873 & & \\
\hline \multirow{4}{*}{ Process management } & Q9 & 0.864 & 0.848 & 0.783 \\
\hline & Q10 & 0.812 & & \\
\hline & Q11 & 0.830 & & \\
\hline & Q12 & 0.844 & & \\
\hline Customer focus and satisfaction & Q13 & 0.836 & 0.895 & 0.664 \\
\hline
\end{tabular}




\begin{tabular}{|c|c|c|c|c|}
\hline & Q14 & 0.875 & & \\
\hline & Q15 & 0.879 & & \\
\hline & Q16 & 0.957 & & \\
\hline \multirow{4}{*}{ Supplier partnership } & Q17 & 0.915 & 0.846 & 0.784 \\
\hline & Q18 & 0.947 & & \\
\hline & Q19 & 0.859 & & \\
\hline & Q20 & 0.947 & & \\
\hline \multirow{4}{*}{ Training and learning } & Q21 & 0.789 & 0.754 & 0.631 \\
\hline & Q22 & 0.794 & & \\
\hline & Q23 & 0.895 & & \\
\hline & Q24 & 0.835 & & \\
\hline \multirow{4}{*}{ Benchmarking } & Q25 & 0.776 & 0.789 & 0.673 \\
\hline & Q26 & 0.753 & & \\
\hline & Q27 & 0.847 & & \\
\hline & Q28 & 0.795 & & \\
\hline \multirow{3}{*}{ Scheduling } & Q1 & 0.803 & 0.884 & 0.664 \\
\hline & Q2 & 0.827 & & \\
\hline & Q3 & 0.789 & & \\
\hline \multirow{3}{*}{ Cost } & Q4 & 0.894 & 0.783 & 0.825 \\
\hline & Q5 & 0.806 & & \\
\hline & Q6 & 0.784 & & \\
\hline \multirow{3}{*}{ Quality } & Q7 & 0.918 & 0.936 & 0.774 \\
\hline & Q8 & 0.904 & & \\
\hline & Q9 & 0.784 & & \\
\hline
\end{tabular}

In this study, the discriminant validity can be assessed using the one measures Fornell and Larcker (1981). Thus, the square roots of the AVE should be more than the correlations among the latent constructs - table 2 shown the discriminant validity result of this study.

Table 2. Discriminant validity result.

\begin{tabular}{|l|l|c|c|c|c|c|c|c|c|c|c|}
\hline \multicolumn{2}{|c}{ Variables } & $\mathbf{1}$ & $\mathbf{2}$ & $\mathbf{3}$ & $\mathbf{4}$ & $\mathbf{5}$ & $\mathbf{6}$ & $\mathbf{7}$ & $\mathbf{8}$ & $\mathbf{9}$ & $\mathbf{1 0}$ \\
\hline $\mathbf{1}$ & HRM recognition & $\mathbf{0 . 7 9}$ & & & & & & & & & \\
\hline $\mathbf{2}$ & Top management & 0.42 & $\mathbf{0 . 8 6}$ & & & & & & & & \\
\hline $\mathbf{3}$ & Process management & 0.53 & 0.35 & $\mathbf{0 . 8 8}$ & & & & & & & \\
\hline $\mathbf{4}$ & Customer focus and satisfaction & 0.32 & 0.54 & 0.24 & $\mathbf{0 . 8 1}$ & & & & & & \\
\hline
\end{tabular}




\begin{tabular}{|l|l|l|l|l|l|l|l|l|l|l|l|}
$\mathbf{5}$ & Supplier partnership & 0.65 & 0.36 & 0.57 & 0.45 & $\mathbf{0 . 8 9}$ & & & & & \\
\hline $\mathbf{6}$ & Training and learning & 0.22 & 0.39 & 0.22 & 0.67 & 0.48 & $\mathbf{0 . 7 9}$ & & & & \\
\hline $\mathbf{7}$ & Benchmarking & 0.52 & 0.43 & 0.43 & 0.35 & 0.13 & 0.33 & $\mathbf{0 . 8 2}$ & & & \\
\hline $\mathbf{8}$ & Scheduling & 0.24 & 0.24 & 0.63 & 0.29 & 0.46 & 0.42 & 0.57 & $\mathbf{0 . 8 1}$ & & \\
\hline $\mathbf{9}$ & Cost & 0.65 & 0.57 & 0.25 & 0.24 & 0.63 & 0.69 & 0.44 & 0.34 & $\mathbf{0 . 9 1}$ & \\
\hline $\mathbf{1 0}$ & Quality & 0.46 & 0.12 & 0.10 & 0.48 & 0.58 & 0.14 & 0.35 & 0.39 & 0.25 & $\mathbf{0 . 8 8}$ \\
\hline
\end{tabular}

Table 2 shows the AVE's square roots for all constructs above the correlations among the latent constructs that indicate this study has sufficient discriminant validity. Descriptive statistics and correlations are presented in Table 3. The results suggested that the arithmetic averages of the variables were greater than the hypothetical average of (3.5), and this indicates the support of the research sample members regarding the vital role played by the critical success factors in increasing the success of the project and the standard deviation of the variables showed slight variations among the respondents' opinions as well as the fact that all the relationships among the basic variables are at the level of significance $(0.05)$.

Table 3. Descriptive statistics and correlations.

\begin{tabular}{|l|l|c|c|c|c|c|c|c|c|c|c|c|c|}
\hline \multicolumn{2}{|c|}{ Variables } & Mean & SD & $\mathbf{1}$ & $\mathbf{2}$ & $\mathbf{3}$ & $\mathbf{4}$ & $\mathbf{5}$ & $\mathbf{6}$ & $\mathbf{7}$ & $\mathbf{8}$ & $\mathbf{9}$ & $\mathbf{1 0}$ \\
\hline $\mathbf{1}$ & HRM recognition & 3.53 & 0.94 & 1 & & & & & & & & & \\
\hline $\mathbf{2}$ & Top management & 3.65 & 0.89 & 0.42 & 1 & & & & & & & & \\
\hline $\mathbf{3}$ & Process management & 3.24 & 0.83 & 0.53 & 0.35 & 1 & & & & & & & \\
\hline $\mathbf{4}$ & Customer focus and satisfaction & 3.73 & 0.84 & 0.32 & 0.54 & 0.24 & 1 & & & & & & \\
\hline $\mathbf{5}$ & Supplier partnership & 3.63 & 0.99 & 0.65 & 0.36 & 0.57 & 0.45 & 1 & & & & & \\
\hline $\mathbf{6}$ & Training and learning & 3.89 & 0.95 & 0.22 & 0.39 & 0.22 & 0.67 & 0.48 & 1 & & & & \\
\hline $\mathbf{7}$ & Benchmarking & 3.21 & 0.83 & 0.52 & 0.43 & 0.43 & 0.35 & 0.13 & 0.33 & 1 & & & \\
\hline $\mathbf{8}$ & Scheduling & 3.75 & 0.98 & 0.24 & 0.24 & 0.63 & 0.29 & 0.46 & 0.42 & 0.57 & 1 & & \\
\hline $\mathbf{9}$ & Cost & 3.07 & 0.87 & 0.65 & 0.57 & 0.25 & 0.24 & 0.63 & 0.69 & 0.44 & 0.34 & 1 & \\
\hline $\mathbf{1 0}$ & Quality & 3.26 & 0.85 & 0.46 & 0.12 & 0.10 & 0.48 & 0.58 & 0.14 & 0.35 & 0.39 & 0.25 & 1 \\
\hline
\end{tabular}

The correlation coefficients in Table 3 indicate a positive relationship between the variables and dimensions of the study. In addition to that, these results suggest that the data is valid for conducting other statistical analysis, especially testing the study hypotheses because the correlation was less than 0.9 .

Since the type of hypotheses for this study are the hypotheses of an impact relationship (measurement of direct effects between variables), the researcher will use the Smart PLS program to test the hypotheses by path analysis, as the coefficients of this type of analysis are like the regression analysis coefficients in the sense that the path analysis provides the same results that it provides. Regression analysis So, there is no reason to present the same results again by regression analysis. Path analysis is based on the idea of least squares used in regression analysis. Table 4 shows the influence relationships between the study variables. 
Table 4. Testing hypotheses.

\begin{tabular}{|l|c|c|c|c|c|c|}
\hline \multicolumn{2}{|c}{ Path } & Estimate & C.R & P & Label \\
\hline HRM recognition & $\rightarrow$ & Scheduling & 0.042 & 4.506 & 0.000 & Supported \\
\hline Top management & $\rightarrow$ & Scheduling & 0.099 & 7.374 & 0.000 & Supported \\
\hline Process management & $\rightarrow$ & Scheduling & 0.118 & 5.102 & 0.000 & Supported \\
\hline Customer focus and satisfaction & $\rightarrow$ & Scheduling & 0.085 & 4.381 & 0.000 & Supported \\
\hline Supplier partnership & $\rightarrow$ & Scheduling & 0.155 & 7.578 & 0.000 & Supported \\
\hline Training and learning & $\rightarrow$ & Scheduling & 0.104 & 3.088 & 0.000 & Supported \\
\hline Benchmarking & $\rightarrow$ & Scheduling & -0.004 & 8.876 & 0.000 & Supported \\
\hline HRM recognition & $\rightarrow$ & Cost & 0.349 & 6.245 & 0.000 & Supported \\
\hline Top management & $\rightarrow$ & Cost & 0.144 & 4.253 & 0.000 & Supported \\
\hline Process management & $\rightarrow$ & Cost & 0.193 & 4.352 & 0.000 & Supported \\
\hline Customer focus and satisfaction & $\rightarrow$ & Cost & 0.356 & 8.698 & 0.000 & Supported \\
\hline Supplier partnership & $\rightarrow$ & Cost & 0.325 & 7.067 & 0.000 & Supported \\
\hline Training and learning & $\rightarrow$ & Cost & 0.323 & 3.457 & 0.000 & Supported \\
\hline Benchmarking & $\rightarrow$ & Cost & 0.270 & 3.364 & 0.000 & Supported \\
\hline HRM recognition & $\rightarrow$ & Quality & 0.349 & 9.855 & 0.000 & Supported \\
\hline Top management & $\rightarrow$ & Quality & 0.144 & 4.554 & 0.000 & Supported \\
\hline Process management & $\rightarrow$ & Quality & 0.193 & 3.475 & 0.000 & Supported \\
\hline Customer focus and satisfaction & $\rightarrow$ & Quality & 0.356 & 2.447 & 0.000 & Supported \\
\hline Supplier partnership & $\rightarrow$ & Quality & 0.325 & 4.357 & 0.000 & Supported \\
\hline Training and learning & $\rightarrow$ & Quality & 0.323 & 4.802 & 0.000 & Supported \\
\hline Benchmarking & & 0.270 & 5.092 & 0.000 & Supported \\
\hline
\end{tabular}

Based on the path coefficients built in the above table using PLS-SEM, most of the study hypotheses are supported as the critical success factors. Their dimensions positively impact the success of the project and its dimensions.

\section{Discussion}

The findings of this study were based on answering the objectives and hypotheses of the research, which were formulated by reviewing the literature related to this topic, and through the data collected using each of the private interviews with several managers working for several electric power projects, as well as collecting data through the questionnaire form. The results of the study analysis revealed that the senior management and project managers in the organization need to observe and follow up on a set of important characteristics such as leadership roles. Hence, the results demonstrate team building and participation and team mental models to aid in developing the project team. Thus, this indicates that project managers need to learn basic 
skills and the technical skills required to lead the project management, related to understanding the other side of the benefits achieved by project management. On the other hand, the results showed a direct positive impact relationship between the critical success factors and their dimensions and the project's success and dimensions. This explains that the reasons for this are due to effective distribution leading to increased quality, cost, and scheduling levels. Finally, the results showed a significant correlation between critical success factors and project success, due to the role of essential elements of success in providing solutions to work problems using various means such as administrative and statistical methods and technical standards.

\section{Limitation and Future Research}

This study includes some limitations that can be handle in future studies. The current study focused on the electric power projects industry sector, so there is a need to conduct more studies on other industries or the service sector. The other limitation is the lack of data. The panel data analysis could bring more accurate results. The current study is cross-sectional, so longitudinal investigation would be more advanced to support the results of the present study with more reliable results.

Regarding the variables, there is a lack of variables that fall outside the employee's mind or composition, such as leadership or entrepreneurial culture. Therefore, there is a need to support the current model with influencing environmental variables. These are the condition for learning and innovation. Because other variables represent personal readiness variables for learning, for example, curiosity and intellectual perseverance, we suggest lengthening the current model to become more accurate in the reached results. The aim of the study was the changes that occurred in the electric power projects industry in southern Iraq, so a comparative study between the results of the current research and learning in other countries that are culturally different from Iraq will provide us with more products to clarify the problem.

\section{Conclusion}

Considering the discussion of the results that have been reached, there is the importance of stimulating the vision and collective participation in drawing the picture of the future that the individuals and the organization aspire to achieve, developing the spirit of cooperation among all the contributors to the project and urging teamwork that serves the success of the project. Thus, to overcome the obstacles and obstacles facing the success of project management through continuous education of the need to choose the most efficient contractors to overcome the problems that hinder the completion of projects and public education that the project is of general interest that achieves the effective contribution of the parties related to the implementation of the project from ministries and government agencies. In addition, treatments must be provided for some cases of delay, in addition to improving the quality and cost through a few series of administrative reviews, activating the subject of the economic and technical feasibility study by the governorate directorates, and placing the necessary tools and machines for work close to the worksite. Hence, the necessity of empowering workers and giving them the freedom to make decisions can solve problems quickly and before they escalate by giving them more powers than it is now. 


\section{References}

[1] Ahmadabadi, A. A., \& Heravi, G. (2019). The effect of critical success factors on project success in Public-Private Partnership projects: A case study of highway projects in Iran. Transport Policy, 73, 152-161.

[2] Al-Abrrow, H., Alnoor, A., \& Abbas, S. (2019). The effect of organizational resilience and CEO's narcissism on project success: Organizational risk as mediating variable. Organization Management Journal, 16(1), 1-13.

[3] Al-Abrrow, H., Alnoor, A., \& Abbas, S. (2019). The effect of organizational resilience and CEO's narcissism on project success: Organizational risk as mediating variable. Organization Management Journal, 16(1), 1-13.

[4] Alias, Z., Zawawi, E. M. A., Yusof, K., \& Aris, N. M. (2014). Determining critical success factors of project management practice: A conceptual framework. Procedia-Social and Behavioral Sciences, 153, 61-69.

[5] Alnoor, A. (2020). Human capital dimensions and firm performance, mediating role of knowledge management. International Journal of Business Excellence, 20(2), 149-168.

[6] Andersen, E. S., Birchall, D., Jessen, S. A., \& Money, A. H. (2006). Exploring project success. Baltic journal of management.

[7] Banihashemi, S., Hosseini, M. R., Golizadeh, H., \& Sankaran, S. (2017). Critical success factors (CSFs) for integration of sustainability into construction project management practices in developing countries. International Journal of Project Management, 35(6), 1103-1119.

[8] Belout, A., \& Gauvreau, C. (2004). Factors influencing project success: the impact of human resource management. International journal of project management, 22(1), 1-11.

[9] Bradley, J. (2008). Management based critical success factors in the implementation of Enterprise Resource Planning systems. International Journal of Accounting Information Systems, 9(3), 175-200.

[10] Fan, D. (2010, July). Analysis of critical success factors in IT project management. In 2010 2nd International Conference on Industrial and Information Systems (Vol. 2, pp. 487-490). IEEE.

[11] Fornell, C., \& Larcker, D. F. (1981). Evaluating structural equation models with unobservable variables and measurement error. Journal of marketing research, 18(1), 39-50.

[12] Gemuenden, H. G., \& Lechler, T. (1997, July). Success factors of project management: the critical few-an empirical investigation. In Innovation in Technology Management. The Key to Global Leadership. PICMET'97 (pp. 375-377). IEEE.

[13] Hair, J.F., Risher, J.J., Sarstedt, M. and Ringle, C.M. (2019), "When to use and how to report the results of PLS-SEM", European Business Review, 31(1), 2-24.

[14] Hietschold, N., Reinhardt, R., \& Gurtner, S. (2014). Measuring critical success factors of TQM implementation successfully-a systematic literature review. International Journal of Production Research, 52(21), 6254-6272.

[15] Ika, L. A., Diallo, A., \& Thuillier, D. (2012). Critical success factors for World Bank projects: An empirical investigation. International journal of project management, 30(1), 105-116.

[16] Mavi, R. K., \& Standing, C. (2018). Critical success factors of sustainable project management in construction: A fuzzy DEMATEL-ANP approach. Journal of cleaner production, 194, 751765.

[17] Müller, R., \& Jugdev, K. (2012). Critical success factors in projects: Pinto, Slevin, and Prescottthe elucidation of project success. International journal of managing projects in business.

[18] Osei-Kyei, R. and Chan, A.P.C. (2017), "Perceptions of stakeholders on the critical success factors for operational management of public-private partnership projects", Facilities, Vol. 35 No. $1 / 2$, pp. 21-38

[19] Pinto, J. K., \& Slevin, D. P. (1989). Critical success factors in R\&D projects. Researchtechnology management, 32(1), 31-35.

[20] Rosacker, K. M., \& Olson, D. L. (2008). Public sector information system critical success factors. Transforming Government: People, Process and Policy.

[21] Thi, C. H., \& Swierczek, F. W. (2010). Critical success factors in project management: implication from Vietnam. Asia Pacific Business Review, 16(4), 567-589. 
[22] Tsiga, Z., Emes, M., \& Smith, A. (2017). Critical success factors for projects in the petroleum industry. Procedia Computer Science, 121, 224-231.

[23] ul Haq, I., Ali, S. M., \& Nawaz, M. T. (2019, March). An analysis of the critical success factors in ICT sector of Pakistan. In 2019 5th International Conference on Information Management (ICIM) (pp. 45-53). IEEE.

[24] Vrchota, J., Řehoř, P., Maříková, M., \& Pech, M. (2021). Critical Success Factors of the Project Management in Relation to Industry 4.0 for Sustainability of Projects. Sustainability, 13(1), 281.

[25] Westerveld, E. (2003). The Project Excellence Model®: linking success criteria and critical success factors. International Journal of project management, 21(6), 411-418.

[26] Zwikael, O., \& Globerson, S. (2006). From critical success factors to critical success processes. International journal of production research, 44(17), 3433-3449. 